\title{
Expanded Table of Contents
}

List of Illustrations

Preface

How to Use this Book

\section{Part I The Debate}

Chapter 1 Debating the Clearances 3

Leaving the Highlands 3

Definitions 6

The Original Controversy $\quad 7$

Contemporary Reactions $\quad 11$

The Modern Debate $\quad 19$

Responsibility 25

Chapter 2 Before the Clearances 26

The Benchmark Problem 26

Conditions of Life $\quad 27$

Security and Food Supplies $\quad 29$

Population before the Clearances $\quad 32$

Change before the Clearances 36

Emigration before the Clearances $\quad 40$

Mobility and Capital Flows $\quad 42$

Chapter 3 The Age of the Clearances 45

Harris, Arichonan and the Uses of Eviction $\quad 45$

The New Sheep $\quad 49$

The Timetable of Clearance 51

Years of Pessimism 56

Landlord Power, Landlord Weakness $\quad 61$

Perceptions, Contemporary and Retrospective 63

Chapter 4 Protest and Resistance during the Clearances 66

The Passive Highlanders 66

The Common Pattern $\quad 67$ 
Three Exceptions $\quad 72$

'A Disgruntled and Pious People' $\quad 76$

Resistance in Perspective $\quad 81$

Chapter 5 The Blame Game $\quad 84$

Reputations and Decline $\quad 84$

Indictments and Good Intentions $\quad 88$

Responsibility for Famine and Decline $\quad 95$

The Dislocated Society $\quad 98$

\section{Part II Documents}

Introduction to Documents 107

1 A Hanoverian blueprint for the Highlands 109

2 Edmund Burt: pre-Clearance reports 111

3 Reports on the Annexed Estates 113

4 Observations of Peter May 116

5 Thomas Pennant, 1769 and $1772 \quad 117$

6 The Hebrides, 1772: the property of Norman Macleod 118

7 Emigration, famine and social structures - Assynt in the $1770 \mathrm{~s}$

8 Emigration, 1772

9 Letter: Allan MacDonald, of Kingsburgh (Skye), to John McKenzie Esq. of Delvine, WS Edinburgh

10 Pre-Clearance emigration, $1774 \quad 122$

11 Johnson and Boswell in the Highlands and Islands 123

12 Matthew Culley's Journal, $1775 \quad 125$

13 Adam Smith 126

14 Henry Home, Lord Kames 127

15 William Gilpin: emigration in $1776 \quad 128$

16 Alexandre de La Rochefoucauld: a French perspective 129

17 Letters from General Mackay, of the Reay estate, to a Tacksman 130

18 Assynt, Sutherland, in the late eighteenth century 131

19 Some observations on Argyll 132

20 Perthshire in the 1790s 133

21 Colonel Alexander Macdonell of Glengarry writes to his agent, 1794

22 Knoydart, $1795 \quad 136$

23 Oral testimonies 136

24 Progress of sheep farming 138

25 Thomas Telford, $1802 \quad 138$

26 Selkirk on emigration $\quad 140$ 
27 Rev. James Hall

28 A common clearance, 1810

29 The Oppression of Numbers - Sutherland, 1817

30 The clearing tenant in a hurry

31 The end of MacKid

32 Sellar's triumph, 1817

33 An internal estate communication 148

34 Clearances and emigration $\quad 149$

35 Clearance 1817-19 150

36 James Loch to Lady Stafford, 3 November 1817

37 A petition 152

38 Patrick Sellar to Lord Reay, 1 May 1819

39 Clearance at Aberscross, Sutherland, 1819

40 Robert Southey on landlords, 1819

41 James Loch, 1820: Improvement in Sutherland 156

42 Observations of General David Stewart of Garth 159

43 Hugh Miller's account of the Island of Rum, $1826 \quad 160$

44 Duncan Shaw to Alexander Hunter, 25 February 1827 (from Benbecula)

45 From the Perth Courier, 1831

46 Sismondi 163

47 Distress in the Highlands, 1837

48 Famine and emigration, $1837 \quad 165$

49 A letter: D. MacPherson to Sir Edward MacArthur, 11 May 1838, from Kingussie [Inverness-shire], North Britain 166

50 From the file of the Inverness Courier, 1841

51 From the Inverness Courier 168

52 Clearance in Harris, 1838-41: evidence of Duncan Shaw 168

53 Testimony of $\mathrm{Mr}$ John Bowie, estate manager, 26 February 1841

55 From the New Statistical Account of Scotland, 1845

56 Lord Henry Cockburn 176

57 Enclosure: A landlord's remarks $\quad 177$

58 An emigrant letter 178

59 Marx and the Highlands 179

60 A Canadian newspaper report on 'Emigrants from the Duke of Sutherland's Estates'

61 Clearance at Arichonan, North Knapdale, Argyll, $1848 \quad 182$

62 Observations of a touring English parliamentarian 184

63 Lord Cockburn on the North Uist clearances, 1849 
64 Evander MacIver to James Loch. Written from Scourie, 8 March 1850

65 Clearance at Strathconan, Whitsunday 1850: an eyewitness account of the episode

66 Clearance: Barra, 1850

67 Emigrant letters

68 From the records of the Highland and Island Emigration Society

69 Boreraig and Suishnish, Skye, 1853

70 Greenyards, Easter Ross, 1853-4

71 Hugh Miller in Eigg, 1845

72 An American view

73 Donald Macleod's reply

74 Reminiscences of Morvern

75 The Leckmelm evictions, 1879

76 A Canadian Highlander on evictions

77 Oral testimonies 205

78 John MacDonald's testimony

79 Gairloch in the 1880s

80 Late-term clearances, 1887

81 Some reflections of Lord Napier

82 The turnover of estates

Chronology

Guide to Further Reading 222

Essay Questions and Projects 226

Works Cited in the Text 228

Glossary $\quad 235$

Statistical Tables 237

Index 239 